\title{
CO-INTEGRATION DAN CONTAGION EFFECT ANTARA PASAR SAHAM SYARIAH DI INDONESIA, MALAYSIA, EROPA, DAN AMERIKA SAAT TERJADINYA KRISIS YUNANI
}

\section{Tara Ninta Ikrima, Harjum Muharam}

Fakultas Ekonomika dan Bisnis, Universitas Diponegoro, Semarang, Indonesia

Info Artikel

Sejarah Artikel:

Diterima Januari 2014

Disetujui Februari 2014

Dipublikasikan September 2014

Keywords:

Co-Integration;

Contagion Effect,;

Islamic Stock Market;

Yunani's Crisis

\begin{abstract}
Abstrak
Penelitian ini bertujuan untuk menganalisis dampak krisis di Yunani terhadap pergerakan harga saham syariah di Indonesia, Malaysia, Amerika Serikat dan Eropa. Selain itu, penelitian ini juga menganalisis co-integrasi dan efek penularan (contagion effect) yang terjadi selama periode ini. Penelitian ini dilakukan karena ada perbedaan antara hasil penelitian tentang US Subprime Mortgage periode krisis tentang dampak pasar saham syariah. Penelitian ini menggunakan VAR (Vector Auto Regressive) dan VECM (Vector Error Correction Model) untuk menguji hipotesis dengan menggunakan data indeks harga saham penutupan mingguan yang diambil dari perwakilan pasar saham syariah masing-masing negara, JII untuk Indonesia, DJIMY untuk Malaysia, DJIMUS dan MSCI untuk Eropa. Hasilnya menunjukkan bahwa Krisis Yunani tidak memiliki pengaruh terhadap pergerakan harga saham Islam di AS, Malaysia, Indonesia, dan Eropa. Namun ada co-integrasi dan penularan berpengaruh terhadap harga saham Islam diempat wilayah saat krisis Yunani itu terjadi.
\end{abstract}

\section{CO-INTEGRATION AND CONTAGION EFFECT AMONG ISLAMIC STOCK MARKETS IN INDONESIA, MALAYSIA, EUROPE, AND USA AT THE GREEK CRISIS}

\begin{abstract}
The objective of the study was to analyze the Greece's crisis impacts toward the movement of Islamic stock prices in Indonesia, Malaysia, USA and Europe. Moreover, this study also analyzed co-integration and contagion effect which occurred during the period. VAR (Vector Auto Regressive) and VECM (Vector Error Correction Model) were used to test the hypothesis using the weekly closing stock price indices taken from the representatives of Islamic stock markets of each country; JII in Indonesia, DJIMY in Malaysia, DJIM in USA, and MSCI in Europe. The result showed that the Greece's crisis did not give any influence toward the movement of Islamic stock prices in USA, Malaysia, Indonesia, and Europe. However; there were co-integration and contagion effect which influenced on Islamic stock prices in those four regions at Greece's crisis time.

JEL Classification: G1, G11
\end{abstract}

Alamat korespondensi : 


\section{PENDAHULUAN}

Krisis yang terjadi di Yunani saat ini, tidak hanya mengakibatkan melemahnya perekonomian di Yunani saja, namun beberapa negara yang berada di dekatnya (terutama daerah Eropa) juga terkena efek dari krisis tersebut. Yunani yang memutuskan untuk merubah mata uangnya dari Drachma menjadiEuro pada tahun 2002 menjadi awal mula terjadinya krisis yang terjadi saat ini. Pada saat itu Yunani rela memalsukan anggaran defisit yang tidak pernah berada dibawah 3\% demi memenuhi syarat yang ditetapkan oleh zona Euro. Tingkat pertumbuhan GDP Yunani yang sejak awal memang tidak stabil apabila dibandingkan dengan negara-negara lain di Eropa mulai runtuh pada tahun-tahun berikutnya. Pendapatan terus melemah terutama sejak tahun 2006 hingga tahun 2009 tanpa ada peningkatan yang signifikan.

Krisis Yunani dimulai tanggal 2 Mei 2010. Hal ini ditandai dengan bantuan sebesar 110 miliar Euro untuk Yunani serta menutup kewajiban pinjaman sampai 2013 dengan menyatakan Bail Outyang disepakati olehmenteri keuangan Eropa. Sebagai timbal balik, Yunani terpaksa harus memangkas defisit melalui efisiensi besar-besaran. Menjelang akhir tahun $2011 \mathrm{~S}$ dan P menyatakan bahwa Yunani resmi menyandang rating CC yang mengundang kegundahan pada pasar saham dunia.

Akibat dari krisis hutang Yunani tersebut, pasar saham dunia kembali mengalami kepanikan. Dow Jones Industrial Average (DJIA) yang bertindak sebagai indeks acuan bahkan mengalami penurunan yang sangat tajam. Kepanikan para pelaku pasar modal ditandai dengan banyaknya investor yang menjual sahamnya, dan hal ini pemicu ambruknya harga saham saat itu. Kepanikan di pasar saham juga dipicu oleh ketakutan akan terjadinya efek domino (contagion effect) terhadap pasar saham negara-negara lain di seluruh dunia.

Pasar modal Indonesia juga tidak lepas dari dampak krisis Yunani ini. Harga saham di Pasar Modal Indonesia mengalami penurunan. Penurunan harga saham di Bursa Efek Indone- sia terjadi pada semua sektor dan berakibat pada turunnya IHSG, indeks LQ45, dan indeks sektoral. JII sebagai indikator harga saham syariah di Indonesia juga mengalami penurunan.

Di Indonesia, harga saham syariah menurun tajam akibat krisis subbprime mortgage yang terjadi beberapa tahun 2008. Namun, saat saham syariah di Indonesia yang diwakili oleh JII (Jakarta Islamic Index) berada dalam proses pemulihan, pasar saham dunia kembali tergerak dengan adanya krisis yang terjadi di Yunani. Pada periode itu kondisi JII sempat beberapa kali mengalami penurunan. Walau tidak setajam saat terjadinya krisis subprime mortgage, penurunan tersebut memperlambat proses pertumbuhan harga saham syariah di Indonesia.

Gambar 1 menunjukan bahwa pada periode Januari 2008 indeks JII berfluktuasi positif hingga menembus angka 500 rupiah. Tidak berselang lama, krisis yang terjadi di Amerika atau yang lebih dikenal dengan sebutan krisis subprime mortgage memaksa hampir seluruh pasar saham di dunia untuk menurunkan. Dampak krisis subprime mortgage JII mengalami penurunan dan berada pada titik terendah, mencapai $\mathrm{Rp}$ 200,-. Pasca terjadinya krisis, harga saham syariah mulai kembali meningkat. Namun sedikit tersendat dengan adanya shock baru yang disebabkan oleh krisis yang terjadi di Yunani.

Berdasarkan pada Gambar 1 terlihat jelas perbedaan efek yang ditimbulkan oleh masingmasing krisis. Pada periode terjadinya krisis subprime mortgage, JII terkena imbas secara langsung sehingga terjadi penurunan yangsangat tajam dalam waktu yang relatif singkat. Pada periode saat terjadinya Krisis Yunani, efek yang ditimbulkan berupa fluktuasi indeks yang relatif rendah serta dalam periode yang panjang. Namun, hal tersebut tidak bisa memastikan ada atau tidaknya co-integration (hubungan jangka panjang) dan contagion effect (efekpenularan) antara pasar saham syariah di Indonesia, Malaysia, Amerika, dan Eropa saat terjadinya Krisis Yunani.

Beberapa penelitian telah dilakukan mengenai contagion effect dan co-integration antar pasar modal. Misalnya, Yunus (2013), Moldovan dan Medrega (2011), serta Kenourgios, 
Tara Ninta Ikrima \& Harjum Muharam / Co-integration dan Contagion Effect Antara Pasar Saham...

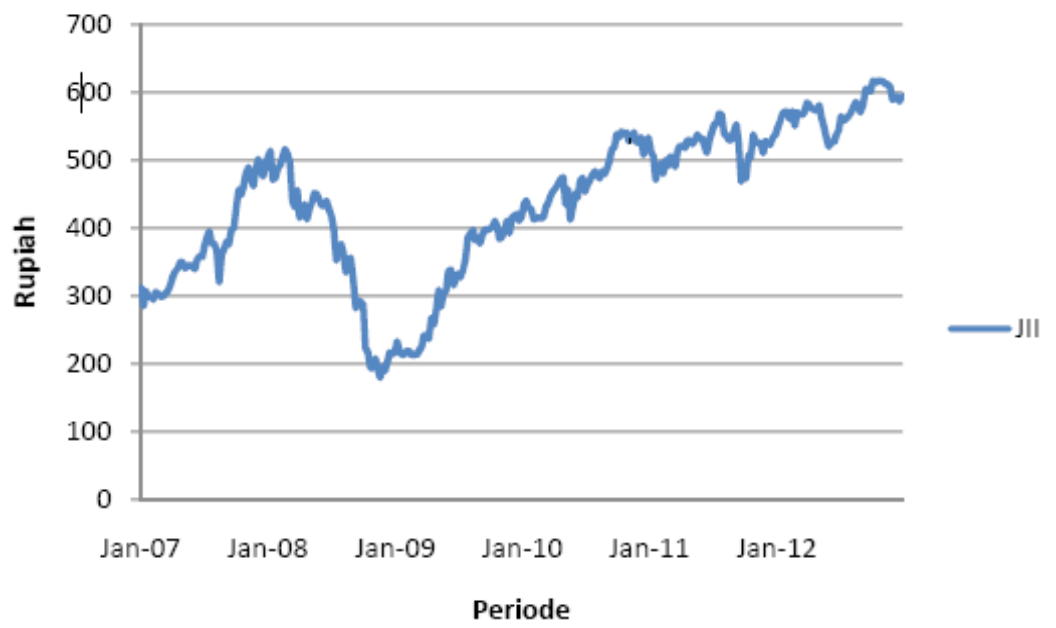

Sumber: data yang diolah (2014)

Gambar 1. Fluktuasi JII selama periode Januari 2007-Januari 2012

Samitas, dan Paltalidis (2011) yang meneliti tentangkorelasi pada pasar saham internasional sebelum dan saat terjadinya krisis United State (US) subprime mortgage. Dalam penelitian tersebut terlihat bahwahubungan antara ketiga indeks yang dipilih yaitu Dow Jones, FTSE, NIKKEI justru menjadi lebih kuat selama periode krisis keuangan. Namun, indeks Dow Jones justru berkorelasi negatif dengan Nikkei selama periode krisis, bahkancenderung lebih rendah daripada periode sebelum krisis.

Penelitian Kizys dan Pierdzioch (2011) membahas mengenai imbasdari krisis keuangan 2008. Dari penelitian tersebut, ditemukan bahwa krisis US subprime mortgage memiliki hubungan yang signifikan dengan jatuhnya hargasaham konvensional di negara-negara CEE (Central and Eastern Europe). Sedangkan penelitian Aloui et al. (2011) serta Moshirian (2011) menguji efek dari krisis global dan efek contagion yang disebabkannya dengan menggunakan pengujian copula. Hasil penelitian menyimpulkan bahwa terjadi interdependensi antar negara Brazil, Russia, India, China dan US.

Banyak negara yang terkena imbas baik langsung maupun tidak langsungdari krisis yang terjadi di Amerika beberapa saat yang lalu. Disisi lain krisis USsubprime mortgage juga menga- kibatkan munculnya penelitian-penelitianmengenai keadaan, efek dan sebab-sebab peristiwa itu terjadi. Dimana salahsatunya juga memaparkan tentang adanya efek kontagion pada krisis yang terjaditerhadap pasar saham global (Guo et al., 2011 \& Lee, 2012).Dalam pasar saham syariah, terdapat beberapa peneliti yang menjadipelopor pada penelitian yang terkait dengan kondisi pasar saham syariah. Misalnya, mengenai ada tidaknya perbedaan atau pengaruh yang signifikan atassaham konvensional dan saham syariah terhadap krisis yang terjadi.

Diantarany aadalah Yusof dan Majid (2007) serta Hengchao dan Hamid (2012). Hingga saat ini belum banyak penelitian yang membahas keadaan pasarsaham syariah saat terjadinya krisis Yunani. Apakah pasar saham syariah saatterjadi krisis Yunani juga mengalami kointegrasi. Seperti apa yang dikatakan oleh Hengchao dan Hamid (2012) dalam penelitiannya yang meneliti pada periodekrisis subprime mortgage, serta bagaimana keadaan pasar saham syariah diIndonesia, Malaysia, Amerika dan Eropamenghadapi krisis Yunani.

Pada penelitian Karim et al. (2010) yang meneliti tentang pengaruh krisis US subprime mortgage terhadap pasar saham syariah (Malaysia, Indonesia, US, UK dan Jepang) dengan menggunakan Johansen-Juselius (JJ) co-integra- 
tion dan menemukan tidak terdapat hubungan kointegrasi antar pasar saham syariah baik periode sebelum krisis (15 Febuari 2006-25 Juli 2007) maupun periode saat terjadinya krisis (26 Juli 2007-31 Desember 2008).

Hal ini bertentangan dengan apa yang disampaikan oleh Tsai (2013) serta Hengchao dan Hamid (2012) yang melakukan penelitian serupa pada 10 indeks pasar saham termasuk pasar saham konvensional dan pasar saham syariah yaitu Nikkei 225, U.S composite, KLCI, Jakarta Composite Index, China 88 index, U.S Islamic Market, Japan Islamic Market, Kuala Lumpur Islamic Index, Jakarta Islamic Index, dan China Islamic Index.

Dalam penelitian Hengchao dan Hamid (2012) dijelaskan bahwa pada periode sebelum terjadinya krisis tidak terdapat hubungan yang signifikan antara pasar saham konvensional dengan pasar saham syariah, sehingga para investor bisa melakukan diversifikasi saham. Namun, pada periode setelah krisis, terlihat bahwa terdapat hubungan equilibrium jangka panjang yang mengisyaratkan bahwa pasar saham satu sama lain saling terintegrasi.

Penelitian Horta (2013) membahas mengenai contagion effect saat terjadinya subprime krisis pada pasar saham Eropa yaitu NYSE Euronext. Model yang digunakan dalam penelitian ini adalah Copula model dimana dengan menggunakan model tersebut dapat dianalisis struktur ketergantungan antara AS dengan pasar saham Eropa dalam periode sebelum dan saat terjadinya krisis. Hasil dari ketiga tes yang dilakukan ditemukan bahwa terdapat efek penularan hampir di semua pasar saham di Eropa.

Penelitian di Eropa juga dilakukan oleh Ahmad et al. (2013) serta penelitian Lee (2012) membahas menggenai Contagion Effect saat terjadinya krisis Subprime Mortgage. Objek dari penelitian ini adalah 20 pasar saham internasional yang di analisis dengan menggunakan GARCH sebagai model yang dipilih.

Penelitian ini menunjukan bahwa 6 negara (Canada, Korea, Hong Kong, Taiwan, Australia, dan New Zealand), 9negara (Canada, Argentina, Jepang, Korea, Hong Kong, Tailand,
Malaysia, Autralia, dan New Zealand), serta 5 negara (China, Hong Kong, Taiwan, Australia, dan New Zealand) pasar saham internasional menunjukan adanya efek kontagion pada satu, tiga dan enam bulan setelah terjadinya krisis subprime pada 2008. Penelitian lain dari Kenourgios et al. (2013)we apply an asymmetric generalized dynamic conditional correlation (AG-DCC juga menemukan ada financial contagion pada saat terjadi krisis di Asia.

Penelitian-penelitian yang telah dilakukan sebelumnya, menunjukan bahwa krisis yang terjadi selalu membawa efek positif atau negatif bagi negara lain.Selain itu krisis juga membawa pengaruh jangka panjang atau jangka pendek terhadap perekonomian negara disekitarnya. Hasil penelitian Lee (2012) dan Horta(2013) juga menyatakan bahwaContagion Effect ada terutama pada pasar saham konvensional selama periode krisis US subprime mortgage.

Pasar saham syariah yang saling terintegrasi ada kemungkinan memiliki hubungan, baik jangka panjang maupun jangka pendek, pada pasar saham syariah yang lain (Ratnaputri, 2013). Pasar modal syariah dunia yang terintegrasi juga diduga akan mengalami Contagion Effectjika salah satu pasar mengalami krisis.Dalam penelitian ini terdapat 4 pasar saham syariah yang menjadi sampel yaitu DJIM (Dow Jones Islamic index) yaitu pasar saham yang mewakili Negara Amerika Serikat selaku indeks acuan dalam pasar saham syariah. Kedua adalah MSCIEurope Islamic Index yang merupakan perwakilan dari tempat terjadinya krisis yaitu Eropa. Ketiga dan Keempat adalah JII(Jakarta Islamic Index) serta DJIMY atau Dow Jones Islamic Index Malaysia yang merupakan perwakilan dari Indonesia dan Malaysia selaku indeks lokal.

Penelitian ini dilakukan untuk mengetahui apakah terdapat kointegrasi dan efek penularan (contagion effect) pada periode sebelum dan saat krisis. Selain itu,dilakukan juga analisis untuk melihat apakah terdapat pengaruh yang timbul akibat krisis yang terjadi di Yunani terhadap pasar saham syariah di Amerika, Malaysia, dan Indonesia, serta melihat pasar saham mana yang paling berpengaruh antara pasar saham syariah 
Tara Ninta Ikrima \& Harjum Muharam / Co-integration dan Contagion Effect Antara Pasar Saham...

di Amerika, Malaysia, Indonesia, dan Eropa dalam volatilitas pergerakan harga sahan syariah di Indonesia pada periode saat terjadinya krisis Yunani.

\section{Pengembangan Hipotesis}

Pasar saham syariah yang saling terintegrasi, menyebabkan munculnya hubungan antara satu pasar saham dengan pasar saham syariah yang lain.Apabila terjadi shock pada suatu pasar saham syariah dalam periode waktu tertentu, ada kemungkinan akan mempengaruhi kondisi pasar saham syariah yang lain. Penelitian yang dilakukan oleh Lee (2012) mengenai contagion effectpada 20 pasar saham internasional saat terjadinya krisis subprime mortgagemenunjukkan bahwa krisis yang terjadi berpengaruh terhadap volatilitas harga saham. Kemudian pengaruh tersebut menyebarke negara-negara lain dalam waktu beberapa bulan setelah terjadinya krisis subprime morgage.

Dari hasil penelitian terlihat bahwa krisis yang terjadi berpengaruh terhadap volatilitas harga saham pada negara yang bersangkutan. Penelitian Karim et al. (2010) meneliti tentang pengaruh krisis US subprime morgage terhadap pasar saham syariah (Malaysia, Indonesia, US, UK, Jepang) menggunakan Johansen-Juselius (JJ) co-integration. Mereka menjelaskan bahwa tidak terlihat adanya co-integration antar pasar saham syariah baik periode sebelum krisis (15 Febuari 2006-25 Juli 2007) maupun periode saat terjadinya krisis (26 Juli 2007-31 Desember 2008).

Penelitian Ye et al. (2012) serta Horta (2013) membahas mengenai contagion effect saat terjadinya subprime morgage crisis pada pasar saham Eropa yaitu NYSE Euronext. Analisis yang digunakan dalam penelitian ini adalah Copula model dimanadengan menggunakan model tersebut dapat dianalisis struktur ketergantungan antara AS dengan Pasar Saham Eropa dalam periode sebelum dan saat terjadinya krisis tersebut. Dari ketiga tes yang dilakukan dinyatakan bahwa terdapat efek penularan (contagion effect) hampir di semua Pasar Saham di Eropa. Penelitian Baek dan Jun (2011) menguji tentang keberadaan financial contagion menggunakan metode yang memungkinkan efek tersebut dapat diobservasi.

Penelitian Moldovan dan Medrega (2011) membahas mengenai korelasi pada pasar saham internasional sebelum dan saat terjadinya krisis US subprime mortgage. Dalam penelitian menunjukkan bahwa hubungan antara ketiga indeks tersebut (Dow Jones, FTSE \& NIKKEI) menjadi lebih kuat selama periode krisis keuangan. Namun sayangnya, indeks Dow Jones berkorelasi negatif dengan Nikkei selama periode krisis, bahkan cenderung lebih rendah daripada periode sebelum krisis. Korelasi dapat dijelaskan oleh fakta bahwa dengan munculnya krisis di Amerika Serikat, investor mulai menutup diri dari pasar saham Amerika dan menginvestasikan uang mereka dalam saham yang diperdagangkan di Bursa Tokyo.

Indeks harga saham penutupan dalam periode yang telah ditentukan digunakan untuk menguji kehadiran contagion effect dan cointegration effect dengan membandingkan hasil pada periode sebelum dan saat terjadinya krisis. Pada proses pengujiannya dilakukan beberapa tahap. Pertama, uji pra estimasi yang terdiri dari uji stasioneritas data (unit root test) dan uji stabilitas VAR (root of characteristic polinominal). Uji Stationer apabila data yang digunakan mengandung akar unit maka akan sulit untuk mengestimasi suatu model dengan menggunakan data tersebut karena tren data tersebut cenderung berfluktuasi tidak disekitar nilai rataratanya.

Maka dapat disimpulkan bahwa data yang stasioner akan cenderung untuk mendekati nilai rata-ratanya dan berfluktuasi di sekitar nilai rataratanya (Gujarati, 2003). Setelah melakukan uji pra estimasi dilanjutkan dengan melakukan uji kointegrasi (co-integration) Engle-Granger untuk melihat apabila ada grup variabel yang tidak stasioner.Variabel yang tidak stasioner akan diteliti lebih lanjut untuk melihat apakah variabel-variabel tersebut saling terkointegrasi. Jika variabel tersebut saling terkointegrasi maka bisa diidentifikasi hubungan jangka panjangnya. Selanjutnya untuk melihat kemampuan suatu variabel dalam mempengaruhi variabel endogen 
lain dilakukan analisis Impuls Respone Fungtion (IRF). Sedangkan untuk melihat kausalitas atau hubungan jangka pendeknya dilakukan analisis Granger Causalitiy.

Penelitian Siskawati (2011) membahas mengenai co-integration antara Jakarta Islamic Index, Kuala Lumpur Shariah Index and Dow Jones Islamic Market Index. Pada penelitian ini menggunakan metode Johansen untuk menguji kointegrasi antar pasar modal dalam rentang waktu 2005 sampai 2007. Hasil analisis yang didapat menyatakan bahwa terdapat hubungan ekuilibrium jangka panjang antara JII, KLSI dan DJIM yang dapat juga diartikan bahwa antara variabel-variabel tersebut terkointegrasi.

Berdasarkan landasan teori dan penelitian terdahulu yang sudah dipaparkan, maka penulis dapat menarik hipotesis berupa: (1) $\mathrm{H}_{1}$ krisis yang terjadi di Yunani berpengaruh terhadap volatilitas harga saham pada pasar modal syariah di Indonesia, Malaysia, dan Amerikasaat terjadinya krisis Yunani; (2) $\mathrm{H}_{2=}$ terdapat kointegrasi antara saham syariah di Indonesia, Malaysia, Eropa dan Amerika pada periode saat terjadinya krisis Yunani; (3) $\mathrm{H}_{3}$ = volatilitas harga saham syariah di Indonesia dipengaruhi oleh pasar saham syariah di Malaysia, Eropa dan Amerika pada saat terjadinya krisis Yunani; dan (4) $\mathrm{H}_{4}=$ Terdapat contagion effect antara saham syariah di Indonesia, Malaysia, Eropa dan Amerika pada saat terjadinya krisis Yunani.

\section{METODE}

Metode analisis yang digunakan dalam penelitian ini adalah metode Vector Auto Regression(VAR) apabila data yang digunakan telah stasioner pada tingkat level. Namun bila data belum stasioner pada tingkat level, maka analisis yang dilakukan akan disesuaikan yaitu dengan menggunakan metode Vector ErrorCorection Model(VECM). Hal ini perlu dilakukan karena bila kita meregresikan variabel-variabel yang tidak stasioner maka akan menimbulkan fenomena spurious regression (regresi palsu). Penggunaan metode ini diharapkan dapat merepresentasikan bagaimana variabel harga saham di suatu negara dapat mempengaruhi variabel yang sama di negara lain dan sebaliknya.

Menggunakan model VAR, impuls response funcion dan variance decompitition dipilih untuk mendeteksi apakah terdapat contagion effect pada periode sebelum dan saat terjadinya krisis melalui tingkat speed of responsenya. Apabila speed of response meningkat, maka dapat disimpulkan bahwa terjadi contagion effect begitu pula sebaliknya. Sedangkan untuk menguji efek kausalitas antara satu saham dengan saham yang lain digunakan granger causality test. Pada penelitian ini penulis akan menganalisis data tersebut dengan menggunakan program ekonometrikaviews yang dilengkapi dengan interpretasinya.

Sampel dari penelitian ini adalah indeks harga saham penutupan di JII, DJIMY, MSCI EuroIslamic Index, dan DJIM pada tahun 2007 hingga tahun 2013 yang didapat dari Bloomberg. Jangka waktu tersebut dibagi menjadi dua periode waktu, yaitu periode sebelum terjadinya krisis (Oktober 2007 hingga April 2010) dan periode saat terjadinya krisis (Mei 2010 hingga April 2013) untuk membandingkan periode sebelum dan saat terjadinya krisis Yunani. Pemilihanpopulasi dan sampel didasarkan dengan alasan sampel mewakili daerah pasar global dan pasar domestik.

\section{HASIL DAN PEMBAHASAN}

Uji stasioneritas dilakukan menggunakan data pada periode 2007 sampai 2012 yang berarti bahwa data periode sebelum dan saat terjadinya krisis digabung menjadi satu. Hal ini dilakukan untuk lebih mengefisienkan proses pengolahan dan analisis hasil yang dilakukan. Sedangkan pada uji berikutnya, data yang digunakan merupakan data yang telah dibagi menjadi dua periode waktu yaitu sebelum krisis September 2007 sampai April 2010 serta periode saat terjadinya krisis yaitu Mei 2010 sampai April 2013.

Berdasarkan Tabel 1 terlihat bahwa semua variabel mengandung akar unit (tidak bersifat stasioner pada level). Hal itu terlihat dari nilai $\mathrm{ADF}$ yang lebih rendah dari pada ni- 
Tara Ninta Ikrima \& Harjum Muharam / Co-integration dan Contagion Effect Antara Pasar Saham...

lai kritis MacKinnon pada level sebesar 1\%, 5\%, $10 \%$ adalah $-3.99166 ;-3.42619 ;-3.1363$. Kemudian untuk merubah supaya data tersebut bersifat stasioner maka dilakukan uji akar unit pada first difference. Setelah dilakukan uji akar unit padafirst difference didapatkan hasil berupa data yang stasioner pada tingkat ini. Terlihat dari nilai statistik yang lebih kecil dari pada nilai kritis McKinnon. Selain itu stasioneritas bisa juga dilihat melalui probabilitanya. Apabila nilai probabilitasnya 0.000 maka data tersebut telah stasioner.

Lag merupakan bagian penting dalam model ini. Apabila lag yang digunakan dalam uji stasioneritas terlalu sedikit, maka residual dari regresi tidak akan menampilkan proses white noise sehingga model tidak dapat mengestimasi actual error secara tepat. Akibatnya, $\gamma$ dan standar kesalahan tidak diestimasi secara baik. Namun demikian, jika memasukkan terlalu banyak lag, maka dapat mengurangi kemampuan untuk menolak $\mathrm{H}_{0}$ karena tambahan parameter yang terlalu banyak akan mengurangi derajat bebas (Harris, 1995).

Tabel 2 menunjukan bahwa semua bintang berada pada lag 2, baik LR, FPE, AIC, SC, maupun HQ. Tanda bintang yang berada disamping angka tersebut merupakan simbol yang memiliki arti dimana lag optimum yang disarankan oleh EViews berada, maka lag optimum yang disarankan oleh EView berapa pada lag ke 2. Pada periode saat terjadinya krisis lag optimal yang disarankan EViews berada pada lag pertamayang terlihat pada Tabel 3 .

Tidak seperti pada periode sebelum terjadinya krisis, pada periode saat terjadinya krisis, Tabel 3 menujukan bahwa lag optimal dari indikator FPE, AIC, SC, dan HQ berada pada lag 1, namun indikator LR menunjukan bahwa lag 3 merupakan lag optimal. Apabila terjadi perbedaan hasil antar indikator maka lag optimal dipilih berdasarkan pada indikator terbanyak,

Tabel 1. Stasioneritas pada Periode Sebelum dan Saat Terjadinya Krisis

\begin{tabular}{ccccccc}
\hline \multirow{2}{*}{ Variabel } & \multicolumn{3}{c}{ Level } & \multicolumn{3}{c}{ First Difference } \\
\cline { 2 - 7 } & Nilai ADF & Prob & Ket & Nilai ADF & Prob & Ket \\
\hline DJIM & -1.419493 & 0.8534 & tidak stasioner & -16.55977 & 0.0000 & stasioner \\
MSCI & -1.817095 & 0.6940 & tidak stasioner & -18.59015 & 0.0000 & stasioner \\
DJIMY & -1.280678 & 0.8904 & tidak stasioner & -15.17323 & 0.0000 & Stasioner \\
JII & -1.567851 & 0.8032 & tidak stasioner & -17.98889 & 0.0000 & Stasioner \\
\hline
\end{tabular}

Keterangan: data diolah menggunakan EViews 6 dengan nilai kritis MacKinnon pada level sebesar 1\%, 5\%, 10\% adalah -3.99166; -3.42619; -3.1363 sedangkan nilai kritis MacKinnon pada first difference adalah $1 \%, 5 \%, 10 \%$ sebesar $-3.99178 ;-3.42625 ;-3.13634$

Tabel 2. Lag Optimal pada Periode Sebelum Krisis

\begin{tabular}{lrlrrrr}
\hline Lag & LogL & \multicolumn{1}{c}{ LR } & FPE & AIC & \multicolumn{1}{c}{ SC } & HQ \\
\hline 0 & $-2995,098$ & NA & $3.24 \mathrm{e}+14$ & 44,76266 & 44,84916 & 44,79781 \\
1 & $-2438,307$ & 1072,030 & $1.01 \mathrm{e}+11$ & 36,69115 & 37,12367 & 36,86691 \\
2 & $-2397,594$ & $75.95852^{*}$ & $7.00 \mathrm{e}+10^{*}$ & $36.32229^{*}$ & $37.10082^{*}$ & $36,63866^{*}$ \\
3 & $-2385,908$ & 21.10397 & $7.48 \mathrm{e}+10$ & 36,38668 & 37,51122 & 36,84366 \\
4 & $-2371,486$ & 25.18454 & $7.68 \mathrm{e}+10$ & 36,41024 & 37,88078 & 37,00782 \\
\hline
\end{tabular}


dalam kasus ini tanda bintang terbanyak berada pada lag 1. Dari sini bisa disimpulkan bahwa lag optimal yang disarankan EViews pada periode sebelum dan saat terjadinya krisis adalah pada lag 1.

Uji kointegrasi bertujuan untuk menentukan apakah variabel-variabel yang tidak stasioner mengalami kointegasi atau tidak. Konsep kointegrasi dikemukakan oleh Engle dan Granger (1987) sebagai fenomena dimana kombinasi linear dari dua atau lebih variabel yang tidak stasioner akan menjadi stasioner. Kombinasi linear ini dikenal dengan nama persamaan kointegrasi dan dapat diinterpretasikan sebagai hubungan keseimbangan jangka panjang diantara variabel.

Tabel 4 menunjukan nilai t-statistik lebih besar dari tabel critical value dengan nilai kritis MacKinnon pada level sebesar 1\%, 5\%, $10 \%$ adalah $-4,027463 ;-3,443450 ;-3,146455$. Sedangkan nilai t-statistik dari residual masingmasing variabel adalah sebesar -9.678795 untuk DDJIM dimana "D" merupakan first difference dari setiap variabel dikarenakan semua variabel stasioner pada tingkat first difference, kemudian -10.22779 untuk DMSCI, -6.351797 untuk DJIMY dan terakhir -10.14504 untuk DJII. Nilai tersebut menjelaskan bahwa terdapat hubungan jangka panjang antar variabel tersebut atauterdapat hubungan kointegrasi.

Pada periode sebelum krisis DJIM hanya dipengaruhi oleh DJIMY yang merupakan turunan dari Dow Jones sendiri dengan koefisien sebesar -1.199269 dan t-statistik sebesar -3.33859. Sedangkan variabel lain tidak berpengaruh terhadap DJIM. Namun, DJIM berpengaruh pada dirinya sendiri dengan koefisien sebesar 1.259684 dan t-statistik sebesar 2.79869. Hasil analisis data tersebut menjelaskan bahwa pergerakan harga saham syariah DJIM hampir tidak dipengaruhi oleh pergerakan harga saham lain kecuali DJIMY, artinya DJIMY tidak dipengaruhi oleh pergerakan harga saham lainnya. Pergerakan harga saham JII dipengaruhi oleh DJIMY dan DJIM. Sedangkan MSCI justru tidak berpengaruh terhadap pergerakan harga sa-

Tabel 3. Lag Optimal pada Periode Sebelum Krisis

\begin{tabular}{|c|c|c|c|c|c|c|}
\hline Lag & $\log L$ & LR & FPE & AIC & SC & HQ \\
\hline 0 & $-2,499,105$ & NA & $1.97 \mathrm{e}+11$ & $3,735,978$ & $3,744,628$ & $3,739,493$ \\
\hline 1 & $-2,331,406$ & $3,228,832$ & $2.05 e+10^{*}$ & $35.09562^{*}$ & $35.52813^{*}$ & $35.27138^{*}$ \\
\hline 2 & $-2,318,468$ & $2,413,869$ & $2.15 e+10$ & $3,514,131$ & $3,591,984$ & $3,545,768$ \\
\hline 3 & $-2,302,963$ & $28.00052^{*}$ & $2.17 \mathrm{e}+10$ & $3,514,871$ & $3,627,324$ & $3,560,568$ \\
\hline 4 & $-2,297,363$ & $9,780,233$ & $2.54 \mathrm{e}+10$ & $3,530,392$ & $3,677,447$ & $3,590,151$ \\
\hline
\end{tabular}

Tabel 4. Stasioneritas Residual Kointegrasi Augmented Dicky-Fuller (ADF)

\begin{tabular}{lll}
\hline \multicolumn{1}{c}{ Variabel } & \multicolumn{1}{c}{ t-statistic } & Prob. $^{*}$ \\
\hline Residual DDJIM & -9.678795 & 0.0000 \\
Residual DMSCI & -10.22779 & 0.0000 \\
Residual DDJIMY & -6.351797 & 0.0000 \\
Residual DJII & -10.14504 & 0.0000 \\
\hline
\end{tabular}

Keterangan: data diolah menggunakan EViews 6 dengan nilai kritis MacKinnon pada level sebesar 1\%, $5 \%, 10 \%$ adalah $-4,027463 ;-3,443450 ;-3,146455$ 
Tara Ninta Ikrima \& Harjum Muharam / Co-integration dan Contagion Effect Antara Pasar Saham...

Tabel 5. Estimasi Vector Autoregression pada Periode Sebelum Krisis

\begin{tabular}{lcccc}
\hline & DMSCI & DJII & DDJIMY & DDJIM \\
\hline DMSCI(-1) & -0.171822 & 0.097311 & -0.075564 & -0.166633 \\
DMSCI(-2) & {$[-1.97556]$} & {$[0.32548]$} & {$[-0.44570]$} & {$[-0.28823]$} \\
& 0.072097 & -0.140288 & -0.020802 & -0.215052 \\
DJII(-1) & {$[2.03092]$} & {$[-1.14960]$} & {$[-0.30061]$} & {$[-0.91136]$} \\
& 0.008073 & 0.040467 & 0.006011 & 0.359096 \\
DJII(-2) & {$[0.38316]$} & {$[0.55870]$} & {$[0.14634]$} & {$[2.56392]$} \\
& -0.004130 & 0.035860 & 0.035425 & 0.079785 \\
DDJIMY(-1) & {$[-0.19465]$} & {$[0.49171]$} & {$[0.85661]$} & {$[0.56578]$} \\
DDJIMY(-2) & -0.024887 & 1.540858 & 1.081521 & 1.213908 \\
DDJIM(-1) & {$[-0.45929]$} & {$[8.27251]$} & {$[10.2394]$} & {$[3.37039]$} \\
DDJIM(-2) & 0.024974 & -1.537980 & -0.081975 & -1.199269 \\
& {$[0.46213]$} & {$[-8.27899]$} & {$[-0.77817]$} & {$[-3.33859]$} \\
C & 0.394363 & 0.111783 & -1.031975 & -0.178396 \\
& {$[25.6220]$} & {$[2.11274]$} & {$[-34.3957]$} & {$[-1.74371]$} \\
\hline R-squared & -0.012444 & 1.507540 & 0.088347 & 1.259684 \\
Adj. R-squared & {$[-0.18377]$} & {$[6.47653]$} & {$[0.66932]$} & {$[2.79869]$} \\
F-statistic & 0.111113 & 4.924075 & -1.194151 & 25.97006 \\
\hline Keterangan $:[]$ m & {$[0.02551]$} & {$[0.32886]$} & {$[-0.14064]$} & {$[0.89698]$} \\
\hline
\end{tabular}

Keterangan : [ ] merupakan t-statistik

ham lainnya.Hasil estimasi autoregression pada periode sebelum krisis disajikan pada Tabel 6 .

Kondisi JII pada periode saat terjadinya krisis dipengaruhi oleh DJIM dan DJIMY dengan koefisien sebesar 0,35 dan 0,67 dengan t-statistik masing-masing sebesar 7,62 dan 3,76. Pada periode ini MSCItidak berpengaruh pada variabel lain. Bahkan MSCI justru dipengaruhi oleh DJIM. Berdasarkan hal diatas dapat disimpulkan bahwa, pada periode sebelum terjadinya krisis bursa saham syariah di Eropa tidak mempengaruhi harga saham syariah di AS, Indonesia dan Malaysia. Pergerakan harga saham syariah di Eropa justru dipengaruhi oleh fluktuasi harga pada pasar saham syariah Malaysia yang diwakili oleh DJIMY. Namun pada periode setelah terjadinya krisis, Eropa justru dipengaruhi oleh pasar saham syariah di Amerika yang diwakili oleh DJIM selaku indeks syariah yang menjadi acuan bagi dunia. Artinya, krisis yang melanda Eropa saat itu tidak terlalu berpengaruh terhadap pergerakan harga saham syariah baik di AS, Indonesia, maupun di Malaysia.

Analisis Impuls Respone Fungtion berfungsi untuk melacak tingkat respon variabel dependen dalam VAR terhadap shock masingmasing variabel. Maka untuk setiap variabel dari persamaan terpisah persatu unit shockakan diaplikasikan pada error dan pengaruh dalam sistem VAR sepanjang waktu akan dicatat. Sehingga jika terdapat variabel $\mathrm{x}$ dalam sistem, dari total impuls respone $\mathrm{x} 2$ dapat disimpulkan 
Tabel 6. Estimasi Vector Autoregression Pada Periode Saat Terjadinya Krisis

\begin{tabular}{lcccc}
\hline & DMSCI & DJII & DDJIMY & DDJIM \\
\hline DMSCI(-1) & -0.036753 & 0.118897 & 0.023113 & -0.191272 \\
& {$[-0.94714]$} & {$[0.85137]$} & {$[0.33279]$} & {$[-0.69392]$} \\
DJII(-1) & 0.022636 & -0.171230 & 0.060820 & 0.102516 \\
& {$[0.99955]$} & {$[-2.10089]$} & {$[1.50049]$} & {$[0.63728]$} \\
DDJIMY(-1) & -0.025883 & 0.676952 & -0.358734 & 0.541429 \\
& {$[-0.51705]$} & {$[3.75756]$} & {$[-4.00390]$} & {$[1.52266]$} \\
DDJIM(-1) & 0.344643 & 0.353275 & 0.074193 & -0.144210 \\
& {$[26.7606]$} & {$[7.62193]$} & {$[3.21868]$} & {$[-1.57638]$} \\
C & 0.276372 & -2.514541 & -0.763763 & -1.384945 \\
& {$[0.42176]$} & {$[-1.06625]$} & {$[-0.65121]$} & {$[-0.29754]$} \\
\hline R-squared & 0.854454 & 0.399584 & 0.146399 & 0.035695 \\
Adj. R-squared & 0.850044 & 0.381390 & 0.120532 & 0.006474 \\
F-statistic & 193.7324 & 21.96190 & 5.659735 & 1.221552 \\
\hline Keterangan $:[]$
\end{tabular}

Keterangan : [ ] merupakan t-statistik

(Brooks, 2002). Hasil analisis pada periode sebelum terjadinya krisis, pasar saham syariah AS tidak menunjukan sikap yang responsif atas shock yang terjadi pada pasar saham syariah Eropa, Indonesia maupun Malaysia. Demikian pula dengan pasarsaham syariah Eropa yang tidak terlalu responsif dalam menyikapi shock yang terjadi di negara lain.

Pada periode saat terjadinya krisis, pasar saham syariah Eropa merespon dengan baik perubahan yang terjadi pada JII, DJIMY, maupun DJIM. Pasar saham syariah Indonesia hanya memberikan respon yang baik pada perubahan pasar saham syariah Malaysia (DJIMY). Selain pada pasar saham syariah Indonesia,pasar saham syariah Malaysia justru memberikan respon yang baik atas shock yang terjadi. Sedangkan pada pasar saham syariah AS yang pada periode sebelum terjadinya krisis hampir tidak memberika respon, pada periode setelah krisis ini mulai menunjukkan respon yang baik terutama atas shock pasar modal syariah Malaysia.

Variance decompotition atau disebut juga sebagaiforecast error variance decompotition adalah salah satu perangkat dalam model VAR yang berfungsi untuk memisahkan variasi dari sejumlah variabel yang diestimasi menjadi komponen-komponen shock atau menjadi variabel inovasi, dengan asumsi bahwa variabel-variabel inovasi tidak berkorelasi. Selanjutnya variance decompotition akan memberikan informasi mengenai proporsi dari pergerakan pengaruh shock pada sebuah variabel terhadap shock variabel lain pada periode sekarang dan periode yang akan datang (Ajija et al., 2011).

Dari data tersebut, dapat disimpulkan bahwa pada periode sebelum terjadinya Krisis Yunani, Pasar saham syariah hampir didominasi oleh DJIM dimana memiliki pengaruh yang sangat tinggi terhadap MSCI dan DJIMY dengan rata-rata sebesar 50\% dan 55\%. Namun, DJIM hanya mempengaruhi JII rata-rata sebesar 3\%. Maka pada periode ini fluktuasi pasar saham syariah di Indonesia tidak terlalu dipengaruhi oleh pasar saham syariah di AS (3\%) maupun Eropa $(0,3 \%)$, justru pasar saham syariah Malaysia yang memiliki pengaruh paling tinggi terhadap pasar saham syariah Indonesia yang mencapai rata-rata sebesar $46 \%$. Pasar saham syariah Malaysia juga berpengaruh terhadap pasar saham 

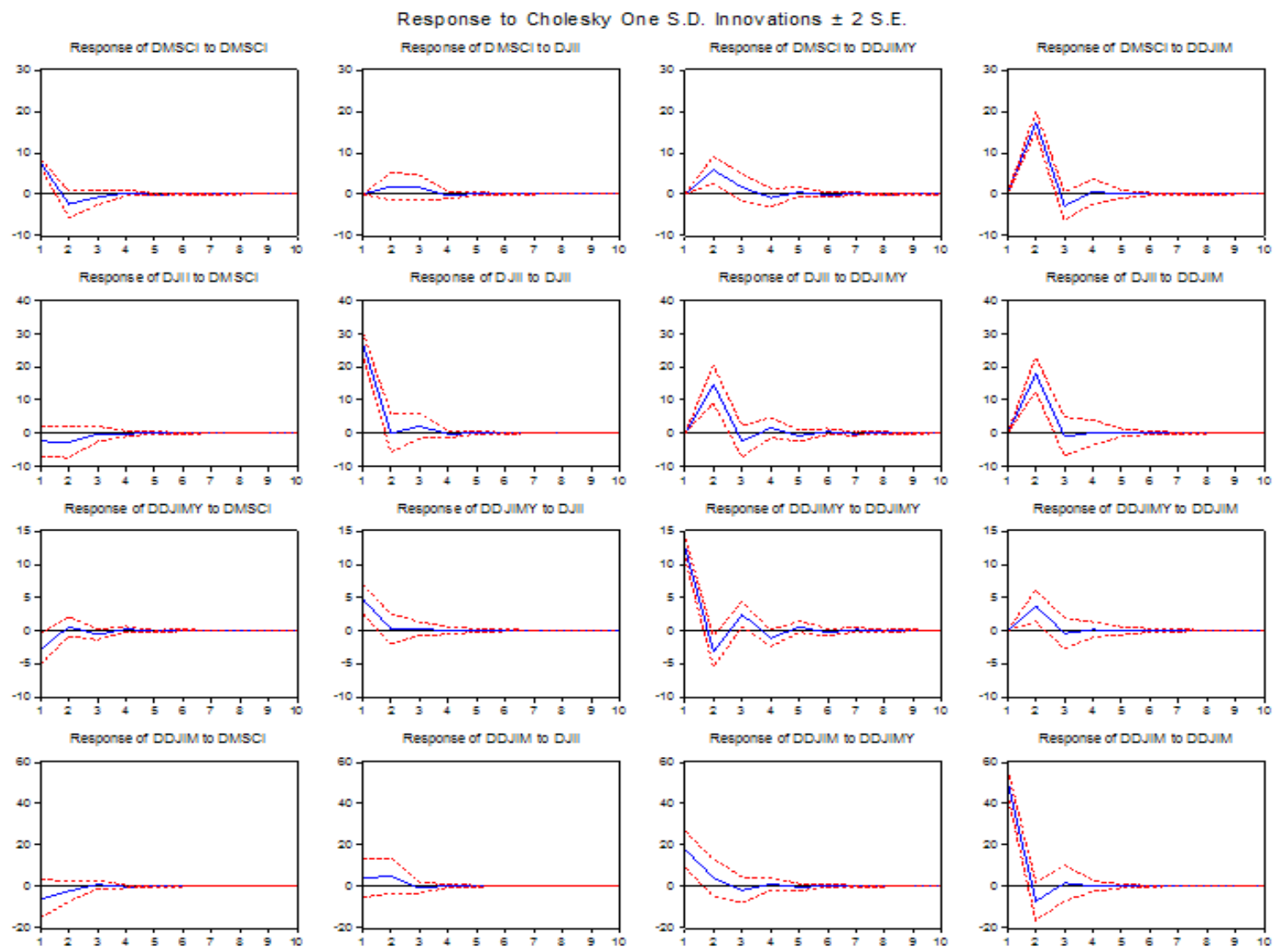

Gambar 2. Impuls Respone Fungtion pada periode saat terjadinya krisis

syariah AS dan pasar saham syariah Eropa masing-masing sebesar $32 \%$ dan $25 \%$. Sedangkan pasar saham syariah Eropa hanya berpengaruh rata-rata kurang dari $1 \%$ atas pasar saham syariah AS, Malaysia, dan Indonesia.

Pada periode setelah terjadinya krisis, MSCI masih tetap tidak terlalu berpengaruh. Bahkan MSCI justru dipengaruhi oleh DJIM rata-rata hingga lebih dari $80 \%$. JII rata-rata hampir $11 \%$ dipengaruhi oleh DJIM dan menunjukan adanya pengurangan dari yang sebelumnya pengaruh DJIM mencapai $30 \%$. Sedangkan pengaruh DJIMY meningkat menjadi rata-rata sebesar $10 \%$. MSCI menpengaruhi JII rata-rata kurang dari $1 \%$.

VECM (Vector Error Corection Model) merupakan bentuk VAR yang teresktriksi. VECM juga merupakan suatu model analisis ekonometrika yang digunakan untuk mengetaui tingkah laku jangka pendek suatu variabel terhadap jangka panjangnya, akibat adanya shock yang pemanen (Kostov \& Lingard, 2000). Model ini digunakan untuk menganalisi variabel time series yang tidak stasioner dan regresi lancung dalam analisis ekonometrika.Hasil analisismenunjukkan bahwapada periode sebelum krisis, variabel yang memiliki hubungan jangka pendek adalah DJIM AS, JII Indonesiadan MSCI Eropa dilihat dari nilai t-hitungnya sebesar 7,48696; -5,94466dan 1.00000. Sedangkan DJIMY Malaysia tidak memiliki hubungan jangka pendek dengan t-hitung sebesar 0.31596 . Maka, pasar modal syariah Malaysia adalah satusatunya variabel yang tidak terlalu berpengaruh atas hubungan jangka pendek dari variabel lain.

Pada Tabel 2 dimana lag optimalnya berada pada lagkedua. Tabel 2 tersebut menunjukan bahwa bahwa MSCI tidak berpengaruh signifikan terhadap variabel JII dan DJIM sedangkan JII tidak berpengaruh signifikan terhadap MSCI. DJIM yang tidak berpengaruh signifikan terhadap JII. Hasil ini menunjukkan bahwa ti- 
dak terdapat hubungan jangka panjang antara kedua variabel.

Hasil analisis pada periode saat terjadinya krisis menunjukan bahwa semua variabel memiliki hubungan jangka pendek. Pada Tabel 7 terlihat besarnya nilai t-hitung, dimana MSCI memiliki t hitung yang tak terhingga, JII sebesar 2.48651, DJIMY sebesar 4.68028 dan DJIM sebesar -15.1013. Hal ini menjelaskan bahwa setelah terjadinya krisis keempat pasar modal yang diwakili oleh masing-masing variabel tersebut memiliki hubungan jangka pendek. Tabel 8 berikut ini adalah hasil estimasi VECM untuk periode saat terjadi krisis dan sudah memasukkan koefisien kointegrasi.

Pada Tabel 8 diketahui lag optimalnya berada pada lag pertama. Tabel 8 menunjukkan bahwa Pasar Modal Syariah Indonesia yang diwakili oleh JII memiliki hubungan jangka panjang dengan Pasar Modal Syariah Eropa (MSCI), Pasar Modal Syariah Amerika Serikat (DJIM) dan Pasar Modal Syariah Malaysia (DJIMY). Secara partial masing-masing variabel saling mempengaruhi yang dapat dilihat dari besarnya t-hitung dari masing-masing variabel yang lebih besar dari t-tabel $(1,96)$. Hasil estimasinya menyimpulkan bahwa setelah terjadi krisis Yunani ke-empat pasar modal syariah ini menjadi terintegrasi.

Kausalitas Granger dilakukan untuk mengetahui pengaruh antara variabel satu dengan variabel yang lain. Jika variabel $\mathrm{X}$ menyebabkan variabel $\mathrm{Y}$ yang berarti nilai $\mathrm{Y}$ pada periode sekarang dapat dijelaskan oleh nilai Y pada periode sebelumnya dan nilai $\mathrm{X}$ pada periode sebelumnya. Kausalitas Granger hanya menguji hubungan antar variabel dan tidak melakukan estimasi terhadap model.

Tabel 7. Koefisien Jangka Pendek Berdasarkan Hasil Estimasi VECM Periode Saat Terjadinya Krisis

\begin{tabular}{clllll}
\hline CointegratingEq: & DMSCI(-1) & DJII(-1) & DDJIMY(-1) & DDJIM(-1) & C \\
\hline CointEq1 & 1.000000 & 0.115894 & 0.561151 & -0.488441 & 0.212510 \\
& & {$[2.48651]$} & {$[4.68028]$} & {$[-15.1013]$} & \\
\hline
\end{tabular}

Tabel 8. Koefisien Jangka Panjang Berdasarkan Hasil Estimasi VECM Periode Saat Terjadinya Krisis

\begin{tabular}{ccccc}
\hline Error Correction: & $\mathbf{D}(\mathbf{D M S C I})$ & $\mathbf{D}(\mathbf{D J I I})$ & $\mathbf{D}(\mathbf{D D J I M Y})$ & $\mathbf{D}(\mathbf{D D J I M})$ \\
\hline CointEq1 & -0.527933 & -1.383045 & -0.792978 & 0.361538 \\
& {$[-6.59631]$} & {$[-4.65350]$} & {$[-5.25145]$} & {$[0.61346]$} \\
D (DMSCI (-1)) & -0.175732 & 0.359691 & 0.102583 & -0.818335 \\
& {$[-5.59543]$} & {$[3.08413]$} & {$[1.73122]$} & {$[-3.53854]$} \\
D (DJII (-1)) & 0.084787 & -0.550930 & -0.003628 & -0.091369 \\
& {$[4.94544]$} & {$[-8.65351]$} & {$[-0.11218]$} & {$[-0.72374]$} \\
D ( DDJIMY (-1)) & 0.105280 & 0.946694 & -0.458658 & 0.273693 \\
D (DDJIM (-1)) & {$[2.69839]$} & {$[6.53417]$} & {$[-6.23080]$} & {$[0.95265]$} \\
& 0.098848 & -0.287683 & -0.312595 & -0.586528 \\
C & {$[2.69851]$} & {$[-2.11492]$} & {$[-4.52309]$} & {$[-2.17449]$} \\
& -0.191003 & 0.309366 & 0.108848 & 1.361830 \\
R-squared & {$[-0.26222]$} & {$[0.11437]$} & {$[0.07920]$} & {$[0.25390]$} \\
Adj. R-squared & 0.919961 & 0.613052 & 0.514997 & 0.402732 \\
F-statistic & 0.916882 & 0.598169 & 0.496343 & 0.379760 \\
\hline
\end{tabular}


Pada periode sebelum terjadinya krisis hasil analisis menunjukan bahwa tidak terdapat hubungan 2 arah DJIM, DJIMY, JII dan MSCI. Sedangkan pada periode saat terjadinya krisis granger causality test yang dilakukan pada lag pertama menunjukan bahwa pada periode saat terjadinya krisis pada DJIM dan DJIMY serta DJIMY dan MSCI yang memiliki hubungan kausalitas 2 arah. Sedangkan MSCI dan DJIMY tidak mempengaruhi JII, namun JII mempengaruhi keduanya.

Berdasarkan pada hasil analisis yang telah dilakukan dengan menggunakan metode VAR (Vector Autoregressive) didapatkan hasil untuk menjawab hipotesis pertama. Pada periode sebelum terjadinya krisis bursa saham syariah di Eropa tidak mempengaruhi harga saham syariah di AS, Indonesia dan Malaysia yang masing-masing diwakili oleh DJIM, DJIMY, dan JII. Pergerakan harga saham syariah di Eropa justru dipengaruhi oleh pasar saham syariah di Amerika yang diwakili oleh DJIM selaku indeks syariah yang menjadi acuan bagi dunia. Artinya, krisis yang melanda Eropa saat itu tidak terlalu berpengaruh terhadap pergerakan harga saham syariah baik di AS, Indonesia, maupun di Malaysia.
Dari kesimpulan yang dibuat bedasarkan hasil analisis ini,dapat digunakan untuk menjawab hipotesis pertama yaitu krisis yang terjadi di Yunani berpengaruh terhadap volatilitas harga saham pada pasar modal syariah di Indonesia, Malaysia, dan Amerika. Maka dapat dinyatakan bahwa $\mathrm{H}_{1}$ tidak didukung yang berarti bahwa krisis yang terjadi di Yunani tidak berpengaruh terhadap volatilitas harga saham pada pasar saham syariah di Indonesia, Malaysia, dan Amerika.

Hipotesis 2 dirumuskan untuk melihat apakah terdapat hubungan jangka panjang(cointegration) antar variabel yang satu dengan variabel yang lain yaitu DJIM, DJIMY, JII, dan MSCI dengan menggunakan uji kointegrasi ADF dan metode VECM (Vector Error Correction Model)pada periode sebelum terjadinya krisis dan pada periode setelah terjadinya krisis.Hasil menunjukan bahwa nilai t-statistik lebih besar dari tabel critical valuedengan nilai kritis MacKinnon pada level sebesar 1\%, 5\%, $10 \%$ adalah $-4,027463 ;-3,443450 ;-3,146455$. Sedangkan nilai t-statistik dari residual masingmasing variabel adalah sebesar -9.678795 untuk DDJIM, -10.22779 untuk DMSCI, -6.351797 untuk DJIMY dan terakhir -10.14504 untuk

Tabel 9. Hubungan Kausalitas Periode Saat Terjadinya Krisis

\begin{tabular}{llll}
\hline \multicolumn{1}{c}{ Null Hypothesis: } & Obs & F-Statistic & Prob. \\
\hline DJII does not Granger Cause DMSCI & 137 & 3.03320 & 0.0839 \\
DMSCI does not Granger Cause DJII & & 0.13376 & 0.7151 \\
DDJIMY does not Granger Cause DMSCI & 137 & 5.93208 & 0.0162 \\
DMSCI does not Granger Cause DDJIMY & & 0.46586 & 0.4961 \\
DDJIM does not Granger Cause DMSCI & 137 & 765.773 & $3 . \mathrm{E}-57$ \\
DMSCI does not Granger Cause DDJIM & & 0.01827 & 0.8927 \\
DDJIMY does not Granger Cause DJII & 137 & 20.8187 & $1 . \mathrm{E}-05$ \\
DJII does not Granger Cause DDJIMY & & 3.20079 & 0.0759 \\
DDJIM does not Granger Cause DJII & 137 & 66.4250 & $2 . \mathrm{E}-13$ \\
DJII does not Granger Cause DDJIM & & 0.78713 & 0.3766 \\
DDJIM does not Granger Cause DDJIMY & \multirow{2}{*}{137} & 10.0004 & 0.0019 \\
DDJIMY does not Granger Cause DDJIM & & 2.98829 & 0.0862 \\
\hline
\end{tabular}


JII dengan nilai probabilitas sebesar 0.000 yang mengindikasikan bahwa terdapat kointegrasi atau hubungan jangka panjang antar variabel tersebut.

Demikian pula pada metode VECM yang dianalisis pada 2 periode. Pada periode sebelum terjadinya krisis, dijelaskan bahwa tidak terdapat hubungan jangka panjang antar variabel yang artinya variabel satu dengan yang lain tidak saling terkointegrasi. Namun, periode saat terjadinya krisis Yunani dijelaskan bahwa terdapat hubungan jangka panjang antara satu variabel dengan variabel yang lain. Artinya, pada periode saat terjadinya krisis terdapat hubungan jangka panjangpada pergerakan harga saham syariah diAmerika, Eropa, Indonesia, dan Malaysia. Dapat disimpulkan bahwa $\mathrm{H}_{2}$ didukung. Dimana dapat juga diartikan bahwa krisis yang terjadi di Yunani berpengaruh terhadap hubungan jangka panjang pada pasar saham syariah di Indonesia, Malaysia,Eropa, dan Amerika.

Hipotesis 3 dirumuskan untuk melihat apakah volatilitas harga saham syariah di Indonesia dipengaruhi oleh pasar saham syariah di negara lain. Metode analisis yang digunakan adalah VAR (Vector Auto Regressive) dengan melihat pengaruh ketiga variabel lain yaitu pasar saham syariah di Eropa, Malaysia, dan Amerika terhadap pasar saham syariah di Indonesia. Hasil analisis menunjukan bahwa kondisi harga pasar saham syariah di Indonesia hampir sebesar 50\% dipengaruhi oleh negara lain yang dalam hal ini diwakili oleh variabel lain yaitu pasar saham syariah di Amerika, Eropa dan Malaysia. Demikian pula pada hasil Estimasi VAR menunjukan bahwa kondisi harga pasar saham syariah di Indonesia dipengaruhi oleh ketiga variabel lain terutama DJIM dari Amerika.

Dengan demikian dapat disimpulkan bahwa volatilitas harga saham syariah di Indonesia yaitu JII baik pada periode sebelum maupun setelah terjadinya krisis Yunani dipengaruhi oleh harga saham syariah negara lain dalam hal ini adalah Amerika, Eropa, dan Malaysia. Proporsi pengaruh terbesar pada volatilitas harga saham di Indonesia didominasi oleh DJIM selaku indeks acuan kemudian DJIMY selaku ne- gara tetangga yang tergolong berpengaruh terhadap harga saham syariah di Indonesia setelah Amerika. Sedangkan Eropa hanya berpengaruh sebesar 3\%. Hasil analisis bisa dilihat di lampiran. Berdasarkan kesimpulan yang dibuat dari hasil analisis tersebut maka didapat dinyatakan bahwa $\mathrm{H}_{3}$ didukung. Artinya bahwa volatilitas harga saham syariah di Indonesia dipengaruhi oleh pergerakan harga saham syariah di negara lain pada periode sebelum dan setelah terjadinya krisis.

Hipotesis 4 dirumuskan untuk melihat apakah terdapat efek penularan atau contagion effect pada pasar saham syariah di Indonesia, Malaysia, Eropa, dan Amerika pada saat terjadinya krisis Yunani. Metode yang digunakan adalah VECM (Vector Error Correction Model) dengan melihat hubungan jangka pendek yang terjadi pada masing-masing variabel dan VAR (Vector Autoregressive) melalui Variance Decompotition.Berdasarkananalisis, dapat disimpulkan bahwa terdapat contagion effect pada pasar saham syariah di Indonesia, Malaysia, Eropa dan Amerika saat terjadinya krisis Yunani. Makaanalisis ini menyatakan $\mathrm{H}_{4}$ didukung. Hal ini dapat disimpulkan dari adanya perubahan-perubahan yang signifikan antara periode sebelum dan sesudah terjadinya krisis.

\section{SIMPULAN DAN SARAN}

Hasil penelitian menunjukkan bahwa pergerakan harga saham syariah di Eropa tidak mempengaruhi harga pasar saham syariah di negara lain (Amerika, Malaysia, dan Indonesia) pada periode sebelum krisis. Sedangkan pada periode setelahnya Eropa justru dipengaruhi oleh Amerika dengan nilai t-statistic mencapai 26.7606 dan sama sekali tidak mempengaruhi pergerakan harga saham syariah di negara lain. Hal ini menjelaskan bahwa krisis yang terjadi di Yunani pada periode tersebut tidak mempengaruhi volatilitas pergerakan harga saham syariah di Amerika, Malaysia, maupun Indonesia.Hasil penelitian menunjukkan bahwa terdapat kointegrasi atau hubungan jangka panjang antara harga saham syariah di Amerika, Eropa, 
Tara Ninta Ikrima \& Harjum Muharam / Co-integration dan Contagion Effect Antara Pasar Saham...

Malaysia dan Indonesia pada periode saat terjadinya krisis. Terbukti dengan melihat hasil analisis kointegrasi menggunakan ADF dan VECM yang menunjukan hasil yang signifikan. Hal ini menjelaskan bahwa antara pergerakan harga saham syariah di Indonesia, Amerika, Eropa dan malaysia saling terkointegrasi.

Hasil penelitian menunjukkan bahwa volatillitas harga saham syariah di Indonesia dipengaruhi oleh pergerakan harga saham syariah di Amerika pada urutan pertama, dilanjutkan dengan Malaysia pada urutan kedua. Pada periode ini peran Eropa dalam mempengaruhi pergerakan saham syariah di Indonesia tidak terlalu besar terlihat dari hasil Variance Decompitition yang hanya sebesa $0,3 \%$. Hal ini menjelaskan bahwa pergerakan harga saham syariah di Indonesia masih dipengaruhi oleh pergerakan harga saham syariah di negara lain dengan tingkat pegaruh yang berbeda-beda. Hasil penelitian menunjukkan bahwa terdapat efek penularan (contagion effect) yang terjadi pada periode saat terjadinya krisis Yunani. Efek tersebut berupa pengaruh yang timbul atas krisis yang mengakibatkan terjadinya perubahan harga saham pada suatu negara. Perubahan tersebut memicu terjadinya pergerakan harga saham di negara lain yang disebut dengan contagion effect.

\section{DAFTAR PUSTAKA}

Ahmad, W., Sehgal, S \& Bhanumurthy, N. R. 2013. Eurozone Crisis And Briicks Stock Markets: Contagion Or Market Interdependence? Economic Modelling. 33: 209-225.

Ajija, S. R., Sari, D.W., Setianto, R. H \& Primanti, M.R. 2011. Cara Cerdas Menguasai EViews. Jakarta: Salemba Empat.

Aloui, R., Aïssa, M.S\& Nguyen, D.K. 2011. Global Financial Crisis, Extreme Interdependences, And Contagion Effects: The Role Of Economic Structure? Journal of Banking \& Finance. 35(1): 130-141.

Baek, I.-M \& Jun, J. 2011. Testing Contagion Of The 1997-98 Crisis In Asian Stock Markets With Structural Breaks And Incubation Periods. Journal of Asian Economics. 22 (5): 356-368
Brooks, C. 2002. Introductory Econometrics for Finance. Cambrige: Cambrige University Press.

Gujarati, D. N. 2003. Basic Econometrics, 4th Edition. New York:McGraw-Hill, Inc.

Guo, F., Chen, C.R \& Huang, Y.S. 2011. Markets Contagion During Financial Crisis: A Regime-Switching Approach. International Review of Economics \& Finance. 20(1): 95-109.

Harris, Richard I. D. 1995. Cointegration Analysis in Econometric Modelling. Great Britain: Prentice Hall/Harvester Wheatsheaf.

Hengchao, Z \& Hamid, Z. 2012. The Impact of Subprime Crisis on Asia-Pacific Islamic Stock Markets.8th International Conference on Islamic Economics and Finance, Kuala Lumpur.

Horta, P. 2013. Contagion Effects in The European: Euronext Stock Markets in The Context of The 2010 Sovereign Debt Crisis.CEPAGEUE Working Paper. 12.

Karim, B.A., Kassim, N. A. M \& Arip, M. A. 2010. The Subprime Crisis And Islamic Stock Markets Integration. International Journal of Islamic and Middle Eastern Finance and Management. 3(4):363-371.

Kenourgios, D., Asteriou, D \& Samitas, A. 2013. Testing For Asymmetric Financial Contagion: New Evidence From The Asian Crisis. The Journal of Economic Asymmetries. 10(2): 129-137.

Kenourgios, D., Samitas, A \& Paltalidis, N. 2011. Financial Crises And Stock Market Contagion In A Multivariate Time-Varying Asymmetric Framework. Journal of International Financial Markets, Institutions and Money. 21(1): 92-106.

Kizys, R \& Pierdzioch, C. 2011. The Financial Crisis and the Stock Markets of the CEE CountriesCzech.Journal of Economics and Finance. 61 (2): 153-172.

Kostov, P \&Lingard, J. 2000. Regime-switching Vector Error Correction Model (VECM) analysist of UK Meat Consumption. EconWPA, Econometrics.

Lee, H. 2012. Contagion in International Stock Markets during the Sub Prime Mortgage Crisis. International Journal of Economics and Financial Issues. 2 (1): 41-53.

Moldovan, I \& Medrega, C. 2011. Correlation of International Stock Markets Before and During the Subprime Crisis. The Romanian Economic Journal. 40: 173-193. 
Moshirian, F. 2011. The Global Financial Crisis And The Evolution Of Markets, Institutions And Regulation. Journal of Banking \& Finance. 35(3): 502-511.

Ratnaputri, W. 2013. The Analysis Of Islamic Bank Financial Performance Using Camel, Shariah Conofrmity And Profitability (SCnP). Jurnal Dinamika Manajemen (JDM). 4(2).

Siskawati, E. 2011.Islamic Capital Market Interconnection: An Evidence from Jakarta Islamic Index to The Regional Islamic Market and Global Islamic Market.Jurnal Akuntansi \& Manajemen.6 (2): 75-85.

Tsai, I.-C. 2013. Volatility Clustering, Leverage, Size, Or Contagion Effects: The Fluctuations Of
Asian Real Estate Investment Trust Returns. Journal of Asian Economics. 27: 18-32.

Ye, W., Liu, X \& Miao, B. 2012. Measuring The Subprime Crisis Contagion: Evidence Of Change Point Analysis Of Copula Functions. European Journal of Operational Research. 222(1): 96-103.

Yunus, N. 2013. Contagion In International Financial Markets: A Recursive Cointegration Approach. Journal of Multinational Financial Management. 23(4): 327-337.

Yusof, R. M \& Majid, M. S. A. 2007. Stock Market Volatility Transmission in Malaysia: Conventional Versus Islamic Stock Markets. JKAU Islamic Eco. 3 (2). 